through which the mouse could be observed. She first of all, for some unknown reason, chiseled a round hole out of the bottom of the box. A newspaper was placed underneath. She had a brood of seven little ones, and with the first bread and water supplied her she pasted up the little wire window; but apparently she had not screened her young from curious eyes sufficiently to her satisfaction by this means, for she cut out with her teeth a circular piece of paper from the news. paper placed beneath the hole in the floor of the cage, and with this she effectually shut herself out from view by attaching it to the wired window. When people went near her young she tried to bite; but as soon as they would go into the wheel their education was, we may suppose, considered complete, for she ceased to take any notice of persons looking at or caressing her offspring.

The writer had a terrier pup, which had the misfortune to be run over by a cart, by which its leg was broken. The injured limb was put up in splints, and apparently to the com. fort of the dog, for he made no attempt to remove them. Fractures heal very readily and quickly in the lower animals, and after a short time the dog was observed to put the wounded leg to the ground and use it. Satisfied with the experiment, it set to work and in a few minutes tore off the splints and strapping, although these had been applied with care to prevent their removal by the animal. The first time this dog was taken out it met a cart coming up a narrow lane. The dog looked about him in evident terror. Afraid to run, and not knowing where to run to escape its old enemy, it sat itself up against a wall and howled.

$$
\text { I am, Sir, yours obediently, }
$$

JefFery A. Marston.

\section{EPIDEMIC OF FEVER IN THE VICINITY OF LIVERPOOL.}

To the Editor of The Lavicet.

SIR, - I have been very much interested by the remarks of your Liverpool correspondent regarding the epidemic of fever in the vicinity of that town.

Seeing that in this epidemic certain cases present the unusual complication of diphtheritic exudation on the tongue and fauces when convalescence is apparently established, that then the patient is "again in a critical state for some days," just as in the epidemic recorded by me (vide The Lancert, Feb. 17th, 1866), and to which your correspondent refers, it would be exceedingly interesting to determine whether this outbreak can reasonably be ascribed to such causes as $I$ enumerated in my account. The poison your correspondent believes to be sui generis; hence much greater interest attaches to the inves tigation. I may remind your correspondent that in one of my cases violent epileptiform seizures occurred with the throat complication, and that the same peculiarity was witnessed and described by Dr. Playne, of Maidenhead (vide The Lancert, March $7 \mathrm{th}, 1866$ ), in a case of his, which he had good reason to believe was contracted in Oban. Was there any such complication in the present epidemic?

I shall look forward with much interest to the "future letter" of your correspondent, and trust that further investigation may elucidate more clearly the relationship between water contamination, defective drainage, and this peculiar form, as I may venture to term it, of enteric fever.

Glasgow, Sept. 1568 .

$$
\text { I am, Sir, your obedient servant, }
$$

D. Campdell Black, M.D.

\section{APHASIA.}

To the Editor of THe LANCET.

SIR,-Your remarks on "Aphasia" interested me much, more especially so through having at this time two patients suffering from this indication of cerebral mischief. Singularly enough, my patients thus suffering are mother and daughter, the latter of whom was seized with an apoplectiform attack some weeks since, resulting in partial paralysis of the right side, aphasia, \&c. The mother, through anxiety, protracted watching, and loss of rest, had an epileptiform convulsion, with subsequent great prostration and aphasia. Should any of your subscribers who take a special interest in this subject wish to see these cases, now under my care, I shall feel pleasure in submitting them to their notice; and, if my proses. sional engagements permit, I will carefully report these cases at length (without logomachy, however), if you have space for me so to do.

I am, Sir, your obedient servant,

Cley-next-the-Sea, Sept. $27,1868 . \quad$ W. Sumpter, M.D.

\section{REDUCTION OF VACCINATORS.}

To the Editor of THE LANCET.

SIR,-In your last number, in reference to the changes taking place as regards vaccination in Islington, you express a belief that the Poor-law Board would not sanction the dis. missal of their old officers. Judging from what has been done elsewhere, you indulge in a vain hope. The parish of St.Luke, E.C., was formerly divided, for the purposes of vaccination, into four districts. Lately it has been altered into one, and the guardians, dismissing their old vaccinators (two of whom have been in the service of the Poor-law Board for twenty years), have appointed a person who in the year 1863 was in business as a chemist and druggist, and who still continues to combine the vending of drugs with his other duties. Let me add that the Poor-law Board have approved of this act, -a specimen of the care they bestow on their old officers.

Sept. 1868.

$$
\text { I am, Sir, your obedient servant, }
$$

\section{LIVERPOOL.}

(FROM OUR OWN CORRESPONDENT.)

THE epidemic of fever which has appeared in the neighbour. hood of Liverpool, at Bootle, Seaforth, and Waterloo, still con. tinues. As there have been various notices about it during the last few days in the local papers and elsewhere, many of which are very incorrect in several particulars, it is as well to repeat here that further inquiries substantiate the correctness of the account in last Saturday's LANCET both as to the num. ber of fatal cases and the localities affected. There have been four deaths since that account was sent, making in all sixteen deaths from the fever. The majority of deaths have been in young people, and chiefly young girls from 13 to 15 years of age.

Of course in such an epidemic as this, the first question that arises alike in the mind of the public and in that of the friends of those attacked is-What is the cause? and it is humiliating to be compelled still to fall back upon vague surmises and offer them as possible explanations, all the while feeling we have no certain facts to go upon. In the present instance, various have been the causes assigned, the most frequent being that of defective drainage. That the whole neighbourhood is badly drained and that it abounds in ditches and stagnant pools, is undeniable. The ditches, dry all the summer, have been-since the rain set in six weeks ago--half full of water, which, from the level nature of the ground, does not run off.

It has also been stated that the traps in connexion with the sewers along the road sides are without water owing to the long drought, and the poisonous gases can thus esiape and impregnate the air. In Liverpool they are periodically exa. mined, cleansed, and flushed, but such is not the custom of the authorities of the infected district.

There are two main sewers-the one at Rimrose, the other at Waterloo-which empty themselves in the sea at the Mersey; neither of these go below water mark, and there are about four hours every tide, eight hours in the twenty-four, when the mouths of these are uncovered, and a most offensive smell is perceived if the wind happens to be towards the land.

The Liverpool and Leeds canal meanders through all this district, though it is anything but " a gently meandering stream" in the poet's sense, being a dark, polluted, almost stagnant stream. Here and there along its banks, flats laden with the midden refuse of Liverpool discharge their contents for removal afterwards by farmers for manuring the land. A week or ten days ago great quantities of small fish were found floating dead on the surface of the water. It was at first sup$p$ ised that they had been intentionally poisoned by cocculus indicus, but it is more probable that they too have imbibed the typhus poison, and died in the same way as the perch described in the last number of THe LANCET as dying in great numbers in the Lake of Geneva of typhus. 